\title{
Improving Inservice Teacher Workshops in Florida1
}

\author{
Martha C. Monroe, Jenny Seitz, Shruti Agrawal, Michelle Aldridge, Sheda Morshed, Elizabeth \\ Swiman, Vicki Crisp ${ }^{2}$
}

The process of education reform has brought a number of changes to Florida's public schools. The movement strives to increase teacher accountability by standardizing the curriculum content (with Sunshine State Standards and benchmarks), assessing student achievement (with Florida Comprehensive Achievement Tests), providing funding to schools where student test scores increase, and reorganizing schools that repeatedly score poorly. EDIS Fact sheet FR114 - "Improving Student Achievement with Environmental Education" (http://edis.ifas.ufl.edu/FR114) provides additional information.

In 2000 the Florida Legislature approved legislation that changes the nature of the teacher professional development system in Florida. School districts will be evaluated every year to make sure that teacher professional development programs are aligned with increasing student achievement and other school improvement documents. Teacher workshops shall primarily focus on subject content as related to Sunshine State Standards, teaching methods, technology, assessment and data analysis, classroom management, school safety, and family involvement. The current focus of professional development in Florida is primarily literacy (reading and writing) and ESOL (English for Speakers of Other Languages). Other academic subject areas (e.g., math, science, social studies) are generally a lower priority for teacher inservice. Teachers will be required to document how their inservice workshops help increase student performance.

In some school districts, professional development providers will have to be certified to conduct workshops for their teachers. To learn how to best meet the needs of local teachers, contact the staff development coordinator in your school district. The North East Florida Education Consortium (NEFEC) plans to offer workshops to train nonformal educators how to work within their 14 school districts.

1. This document is FOR 109, one of a series of the School of Forest Resources and Conservation Department, Florida Cooperative Extension Service, Institute of Food and Agricultural Sciences, University of Florida. Original publication date February 2005. Visit the EDIS Web Site at http://edis.ifas.ufl.edu.

2. The authors developed these suggestions during a joint student and professional meeting at the University of Florida in December, 2004 to serve the Project Learning Tree program in the State of Florida. Martha C. Monroe, Associate Professor, School of Forest Resources and Conservation; Jenny Seitz, Project Learning Tree State Coordinator; Shruti Agrawal, Graduate Student, School of Forest Resources and Conservation; Michelle Aldridge, Communications Coordinator, UF Clean Water Campaign; Sheda Morshed, Graduate Student, School of Natural Resources and Environment; Elizabeth Swiman, Graduate Student, Department of Wildlife Conservation and Ecology; and Vicki Crisp, Program Development and Training Specialist, North East Florida Educational Consortium.

The use of trade names in this publication is solely for the purpose of providing specific information. UF/IFAS does not guarantee or warranty the products named, and references to them in this publication does not signify our approval to the exclusion of other products of suitable composition. 
To increase their usefulness to educators, workshop facilitators should be familiar with terms and concepts now used to describe Florida's professional development. These terms should be incorporated into inservice programs. This fact sheet defines the terms that are most helpful and provides suggestions for planning, advertising, delivering, and evaluating workshops to meet the needs of our teachers. Project Learning Tree (PLT) workshops are used as an example of how nonformal education facilitators could adapt their workshops to better address the new professional development system.

\section{Individual Professional Development Plan (IPDP)}

Every educator creates this working document by listing the subject areas, based upon identified student needs, that he/she wants to improve by attending professional development workshops. The challenge is for the educator to find appropriate workshops that meet his/her different needs. A workshop with an interdisciplinary focus covering more than one subject area would be beneficial because it helps meet many teachers' needs simultaneously. PLT workshops often link subject content areas together with all activities at a workshop. Facilitators can ask educators how activities modeled at workshops fit into their IPDP.

\section{School Improvement Plan (SIP)}

Each school administration creates a working document listing areas it wants to concentrate on school-wide in order to increase student learning. When presenting the benefits of your workshop to administrators, ask them what their SIP is focused on to help you obtain permission to do a workshop at their school. For example, the SIP may call for increasing reading scores on the FCAT. PLT Facilitators can discuss conducting a PLT and Reading workshop that focuses on interdisciplinary activities with reading elements. In addition, teachers can meet their IPDP goals by attending PLT workshops that also align with the SIP.

\section{Sustained Professional Development}

Professional development programs need to allow for educators' to build mastery level skills and receive sufficiently sustained training to develop these skills. The basic six-hour PLT workshop needs to be revised to meet educator's new needs. Consider the length and the depth of coverage of the materials when developing a workshop. To sustain skill-building, a one-day workshop can be turned into a multi-day workshop or one that meets several times throughout a semester. The additional time allows educators to practice and develop skills and increase their knowledge in particular subject areas. A PLT facilitator can model the use of activities to reinforce concepts and allow participants time to think of and discuss ways to incorporate activities into their existing curriculum. Part of the workshop could also include having participants lead activities. Providing time to go through activities and conduct them in front of their peers allows educators to receive feedback on ways they can improve their delivery and enhance the activity for their own students. Dividing the workshop into several meetings over a semester allows educators to try the activities in their classrooms and come back to discuss successes and challenges. Educators can work together to find the best ways to utilize PLT in their classrooms.

\section{Use of Technology}

Incorporating educational technology into a PLT workshop is simple, providing one has the technology resources at hand. There are many ways to incorporate technology into a PLT workshop. One is to use computer technology. A PowerPoint ${ }^{\circledR}$ presentation can be used to introduce the PLT program. Later in the workshop, participants can use digital cameras to record images of natural areas and display them in a presentation for the group. This technique shows educators how technology can be used to present information and gives them time to work with technology in the same way they would use it with their students. A set of forester's tools is also technology. Inviting a forester to the workshop to demonstrate how he/she uses the various tools in the field can be incorporated into a classroom presentation. Simply using a VCR or DVD player to 
show an informational video is also technology. In addition, the use of graphing calculators, digital probes, graphing software, and Internet resources are other examples. When possible, facilitators should provide opportunities for teachers to learn, use, and grasp educational technology that they can use in their own classrooms.

\section{Professional Development Target Areas}

Professional development programs should focus on one or more target areas identified by the state. These eight major areas are Sunshine State Standards (SSS), subject content, teaching methods, technology, classroom management, school safety, family involvement, and assessment and data analysis. Finding out about the IPDPs and SIPs of the participants prior to the workshop could help the facilitator understand what target areas schools and teachers need to address. Table 1 summarizes how PLT workshops can address the eight identified target areas for professional development.

\section{Learning Communities}

Learning communities are small groups of teachers that support their own professional development through meetings, discussion, and study that is relevant to their teaching practices over the course of a semester or year. PLT Schools may find it easy to develop a learning community around teachers using the outdoors as a study site. PLT workshops can support the development of learning communities by providing suggestions of books for book club discussions and classroom tools, providing the names and contact information for other PLT-certified educators in their district, and encouraging educators to use the program to support the instructional models of issue investigation and service learning in their classrooms. A community of educators can explore the community issues that students identify and determine the teaching methods that are best for their own community of learners.

\section{Transfer of Learning to Students}

An important outcome of any professional development experience is that the knowledge and skills gained in the workshop are used to improve teaching and learning. In the case of PLT workshops, this is often done when teachers participate in activities and discuss how they could use these activities in their own classrooms. To help reinforce their good intentions, send out email reminders and postcards several weeks following the workshop. In addition, a letter to each teacher's principal (with a copy to the teachers) could introduce the new teaching techniques that should be visible in their classrooms. Beyond encouraging teachers to use PLT, teachers will need to document that students have learned about the environment or have gained reading or math skills because of their PLT workshop. You could suggest that teachers keep copies of student PLT activity worksheets and note what they would change the next time to increase student achievement.

\section{Coaching and Mentoring}

Teachers often need assistance to begin to use new skills and teaching methods. If facilitators could be available to assist teachers in the classroom, teachers will be more likely to take students outdoors and use PLT activities. PLT facilitators could offer to meet with learning communities or sponsor advanced workshops to increase teachers' comfort level with the teaching methods. PLT Schools may be best suited to support teachers with coaching and mentoring because each school has a PLT Coordinator who can provide assistance to teachers.

\section{Web Resources}

The World Wide Web provides an enormous number of resources and possibilities for assistance to teachers. PLT Facilitators can hand out a reference sheet to help make teachers aware of Web sites that are relevant to what teachers and students need to understand forest resources. The Florida PLT Web site (http://sfrc.ufl.edu/plt) will soon be structured to encourage teachers to share ideas about activities and ask questions. Adaptations they have made to activities would be particularly helpful to other teachers. Strategies for using PLT activities to address SSS could also be listed. Teachers can join the PLT listserv of educators and facilitators in order to share resources. Several sites (http://sfrc.ufl.edu/plt/Resources/Resourceindex.htm) 
have Web resources for teachers and students, supporting their use of technology.

\section{Student Change}

The ultimate goal of teacher professional development is to increase student learning. PLT facilitators can help teachers report on student change by using the assessment elements of each activity to measure student learning and keeping a portfolio documenting student growth. For some key concepts, a PLT handout with sample quiz questions could be useful for teachers who wish to assess student knowledge with a pre-post test. Facilitators could also remind teachers in the workshop that research on environmental education programs tells us that PLT programs increase student knowledge of ecological principles. Students exposed to PLT showed gains in environmental knowledge and positive attitude shifts, particularly in grades two through eight (

http://www.plt.org/about/

PLT\%20Exec\%20Summary.pdf).

\section{Action Research}

The new professional development system encourages teachers to use action research principles to examine and improve their own practice. Although a PLT workshop cannot teach action research methods, a facilitator could mention the types of research questions that PLT activities could support. Teachers could compare the active involvement and learning of lower-achieving youth during in-class activities and outside activities (outdoors activities are often credited with engaging students who perform poorly in traditional classrooms), or explore the involvement of girls in science-based activities that involve trees and wildlife as opposed to chemistry and physics. Teachers could also explore their own comfort level with becoming a facilitator of student involvement instead of a lecturer of information. For more information about action research, direct teachers to http://reach.ucf.edu/ CENTRAL/ Action\%20Research/index.html .

\section{Summary}

This fact sheet provides a number of concrete suggestions and key phrases that educators and their administrators are using to describe professional development in Florida. The more nonformal educators can use these terms and comply with these strategies, the more relevant their workshops will be for Florida teachers. And the more Florida teachers participate in meaningful environmental education workshops, the closer we will be to building a citizenry that understands and cares about our natural resources. 
Table 1. Professional Development Target Areas

\begin{tabular}{|c|c|}
\hline Target Area & PLT Connection \\
\hline Sunshine State Standards & $\begin{array}{l}\text { Familiarize educators with the PLT Web site to identify the SSS correlated to } \\
\text { each activity used in the workshop. The standards and benchmarks govern } \\
\text { what is taught. Everything a teacher does must relate to a standard. Engage } \\
\text { teachers in an exercise to illustrate how benchmarks can be addressed with } \\
\text { each activity. Choose activities that emphasize subject areas identified in } \\
\text { schools. }\end{array}$ \\
\hline Subject Content & $\begin{array}{l}\text { Content is important in the context of the standards. Highlight several } \\
\text { activities that focus on one or more subject content areas. Point out how } \\
\text { specific skills such as reading comprehension can be addressed through } \\
\text { selected activities. Also, show the natural integration of subject areas found } \\
\text { in most activities. }\end{array}$ \\
\hline Teaching Methods & $\begin{array}{l}\text { Allow teachers to practice implementing an activity as though they were } \\
\text { students. Conduct a follow-up discussion on the teaching strategies used in } \\
\text { that activity and how the activity addresses various learning styles. } \\
\text { Information on learning styles can be found in the Facilitator Handbook, } \\
\text { pages 55-59. }\end{array}$ \\
\hline Technology & $\begin{array}{l}\text { Demonstrate how tools can be used to understand forest resources and the } \\
\text { environment. Demonstrate how teachers can use video, PowerPoint }{ }^{\circledR} \text {, digital } \\
\text { probes, and Web sites to enhance instruction. Invite a natural resource } \\
\text { professional to the workshop to demonstrate the use of the technology } \\
\text { he/she uses in the field. A forester can bring his/her tools that demonstrate } \\
\text { technology used in field work. }\end{array}$ \\
\hline Classroom Management & $\begin{array}{l}\text { Allow teachers to discuss successful ways they handle classroom } \\
\text { management during interactive and outdoor lessons. Demonstrate the } \\
\text { benefits of using small groups, clear instruction, and follow-up questions. } \\
\text { Allow teachers to simulate student behavior during sample activities and } \\
\text { elicit their suggestions. See Facilitator Handbook pages } 16-24 \text {. }\end{array}$ \\
\hline School Safety & $\begin{array}{l}\text { Using the outdoors for learning could put some students at risk of accidents. } \\
\text { Discuss how to minimize risks during workshops and model good field trip } \\
\text { management strategies, e.g., stress the importance of familiarity with the } \\
\text { field trip site. }\end{array}$ \\
\hline Family Involvement & $\begin{array}{l}\text { Use parent volunteers in the PLT workshop or suggest that teachers bring } \\
\text { parents to the workshop as part of their teaching team. Encourage the use } \\
\text { of parents with PLT activities to help manage small groups and field trips. }\end{array}$ \\
\hline Assessment \& Data Analysis & $\begin{array}{l}\text { PLT activities have excellent discussion questions that enable teachers to } \\
\text { engage students in higher order thinking skills. Encourage the use of the } \\
\text { twenty-five FCAT-like prompts created to go with nine PLT activities for } \\
\text { different grade clusters. These prompts can be downloaded off of the PLT } \\
\text { Web site. }\end{array}$ \\
\hline
\end{tabular}

